\title{
Crustacean larvae distribution in the coastal upwelling zone off Central Chile
}

\author{
B. Yannicelli ${ }^{1,2, *}$, L. R. Castro ${ }^{1,2}$, W. Schneider ${ }^{1}$, M. Sobarzo ${ }^{1}$ \\ ${ }^{1}$ Departamento de Oceanografía, Facultad de Ciencias Naturales y Oceanograficas, and ${ }^{2}$ Laboratorio de Oceanografia \\ Pesquera y Ecología Larval (LOPEL), Universidad de Concepción, Casilla 160C, Concepción, Chile
}

\begin{abstract}
We present data on the stage abundance and spatial distribution of 5 taxa of crustacean larvae whose adult populations inhabit different depth ranges in the coastal area of central Chile (35 to $37^{\circ} \mathrm{S}$ ). Our goal was to identify the relationship between the timing and depth range of larval release, with larval depth distribution and behavior, and offshore transport during early upwelling season (November) and upwelling reversal (March). Emerita analoga larvae were mainly released in the intertidal off phase in the season of maximum upwelling intensity. E. analoga was the shallowest larvae in this study, the most widespread in the horizontal plane and no diel vertical migrations were observed. Blepharipoda spinimana, another intertidal species, was always restricted to coastal stations and were mainly released during summer. It is a shallow species and, at our sampling scale, we could not identify vertical behavior. Libidoclaea granaria larvae were released in the continental shelf during the more intense upwelling season (November). Zoea I were widespread horizontally and zoea II appeared closer to the coast. They did not show vertical migration, they were found widespread in the water column and they were the deepest larvae. Larvae that migrated vertically (Neotrypaea uncinata and Pagurus spp.) were released over a long period during the upwelling season (summer months), from the subtidal environment. Sub-surface waters were characterized by low oxygen and low temperature. Larval distribution depended on the spatial structure of upwelling circulation, larval behaviour and physiological tolerances as well as on the depth and timing of larval release.
\end{abstract}

KEY WORDS: Crustacean larvae $\cdot$ Upwelling area $\cdot$ Vertical distribution $\cdot$ Larval transport · Across shore distribution · Spawning timing

Resale or republication not permitted without written consent of the publisher

\section{INTRODUCTION}

Advection during the larval phases of benthic organisms, which results from the interaction of physical oceanographic processes and larval behaviour, has been suggested as a key factor determining site specific settlement strength. Therefore they influence benthic population and community dynamics (Connolly \& Roughgarden 1998, Wing et al. 1998a). In eastern boundary current (EBC) systems, the temporal and spatial dynamics of wind-driven coastal upwelling is thought to influence larval retention, concentration, survival, transport and hence recruitment in both vertebrates and invertebrate populations (Lundquist et al. 2000, Botsford 2001, Guisande et al. 2001, Flores et al.
2002). Temporal upwelling dynamics involve intra annual cycles of upwelling intensity that affect offshore/onshore advection of plankton and surface nutrient enrichment. Inter-annually, varying upwelling intensities correlate with both the expansion and contraction of the latitudinal range of species (Sorte et al. 2001), and their recruitment strengths (Connolly et al. 2001). Spatially, the local topography and coastline geometry enhance the development of mesoscale circulation features such as jets, filaments, eddies and upwelling shadows. Upwelling shadows for example, might lead to the retention of organisms in coastal sites down current from capes and points during upwelling events (Wing et al. 1998b). Upwelling fronts influence meroplankton coastal distribution (Bjorkstedt et al. 
1997). Eddies can retain organisms and/or maintain production sufficiently high for larvae to feed (Kasai et al. 2002, Nishimoto \& Washburn 2002), and filaments might transport larvae offshore (Rodriguez et al. 2001, Hernández-León et al. 2002).

The coupling of timing and location of larval release with favourable spatio-temporal environmental conditions enhance larval survival and recruitment (Cury \& Roy 1989, Hinkley et al. 2001, Stenevik et al. 2003). If advection is a relevant determinant for the success of larvae, then species-specific life history traits such as spawning timing and location can be in tune with advective environmental cycles (e.g. seasonal upwelling cycle). However, the release, occurs within a species specific depth range, and an overall oceanographic condition (e.g. upwelling circulation) might affect larvae released from different depths during the same season in opposite ways (e.g. shallow release offshore advection, sub-surface release onshore advection).

In addition to the adult control of spawning timing and location, larval behaviour plays a role in its own advection. Behaviour regarding vertical distribution control interacts with prevailing hydrodynamics to shape distribution patterns, transport dynamics and

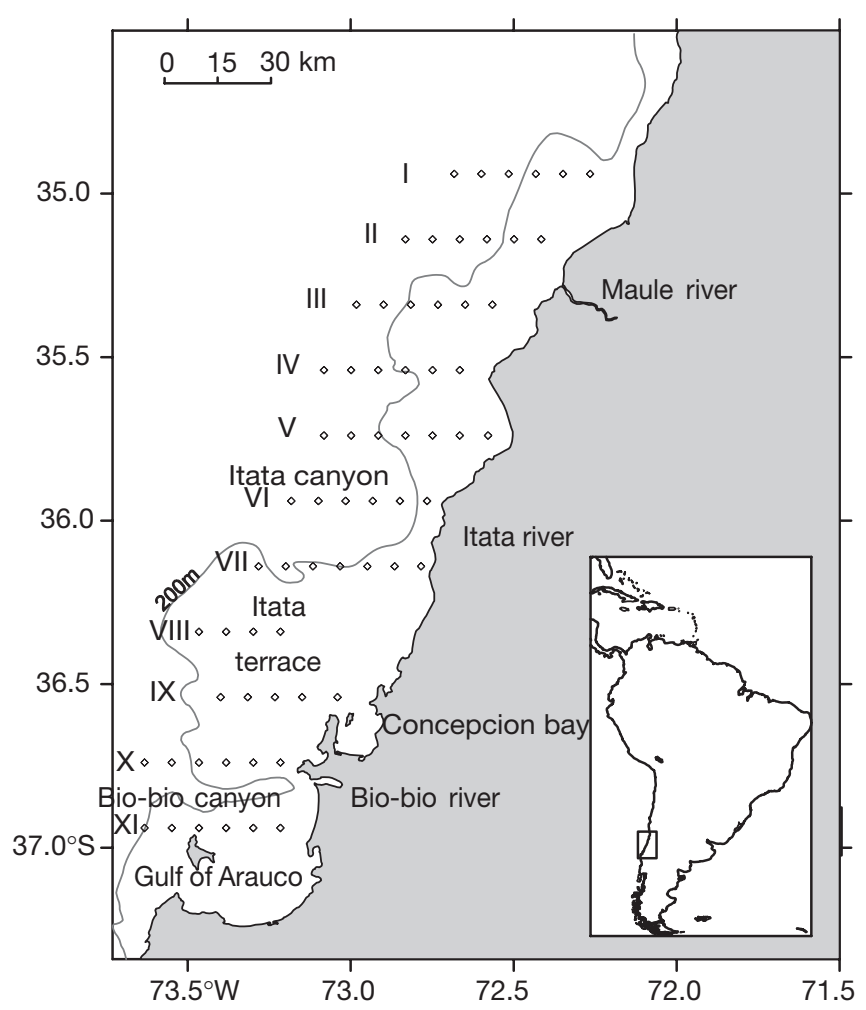

Fig. 1. South Central Chile coastal area with positions of CTD stations during November 2001 cruise. Roman numerals = transects settlement patterns (Sponaugle et al. 2002). While surface dwelling organisms might be advected offshore during upwelling events and they might later be transported shoreward during relaxation, the opposite is true for deep dwelling zooplankton (Shanks 2000, 2002, 2003, Sundby et al. 2001, Garland et al. 2002). Those organisms that vertically migrate between water layers flowing in opposite directions might be more concentrated nearshore (Peterson et al. 1979, Castro et al. 1993) reducing offshore loss and remaining in a food rich media. Crustacean larvae in particular might show complex vertical swimming behaviours. Semi-diurnal, diurnal or ontogenetic depth regulation has been described in a large set of crustacean species, and might arise from endogenous biological rhythms or environmentally induced behaviours (Forward \& Tankersley 2001, Naylor 2005). Mechanisms favoring adequate larval advection could appear during either the adult or larval phase. A relationship between larval vertical distribution and time of spawning has been suggested for larval fish, those that are spawned during the main upwelling season are widespread in the water column (Olivar 1990). Those organisms that release eggs (larvae) in surface waters might show a peak of spawning off phase with the main upwelling season (Castro et al. 2000).

In this paper, we analyze the spatial distribution and abundance of the stages of 4 species and 1 genus of decapod crustacean larvae in the upwelling area of south central Chile (Fig. 1). Species were chosen according to contrasting depth ranges of adult habitat. We aimed to identify the relationship between larval depth distribution, offshore distribution and the timing and depth range of larval release. We expected to find strategies either in the adult or larval phase that tended to minimize offshore advection. For example, larger numbers of early stages of non-migrating surface larvae should be found offphase with the main upwelling season, or extended spawning periods in species with migrating larvae. The ontogenetic distribution (across-shore spreading and clumping) as a consequence of vertical distribution, hatching period and depth, should evidence contrasting mechanisms of shelf retention. For example, surface stages that show limited depth control should appear more widespread, less clumpy and farther offshore during upwelling than species that show depth control. In addition, deeper larvae should approach the coast during prevalence of upwelling winds.

We present data from 2 surveys conducted in spring and late summer along central Chile. Hydrographic data and zooplankton stratified samples allowed the identification of major oceanographic features in the area, and vertical and horizontal distribution patterns of crustacean larval stages. Our data suggested a rela- 
tionship between larval across-shore and vertical distribution, and adult spawning timing and depth range. However, offshore distribution was strongly influenced by coastal geography.

\section{MATERIALS AND METHODS}

Area studied. The study area $\left(35\right.$ to $\left.37^{\circ} \mathrm{S}\right)$ is located at the coastal (shelf) edge of the Humboldt Current system, a major EBC with a surface flow towards the equator. Prevailing winds during austral spring and summer are southwesterly, and hence favor coastal upwelling conditions. Winds reverse to northerly and northwesterly directions during austral autumn and winter with some transitional periods in April and August (Arcos \& Navarro 1986). The coastline of Chile within our study area ( 35 to $37^{\circ} \mathrm{S}$ ) has an approximate alignment of $25^{\circ}$ east of north. However both coastal orientation and bottom topography change markedly within a small latitudinal range (Fig. 1). The continental shelf between 35 and $35.6^{\circ} \mathrm{S}$ is relatively narrow (15 nautical miles offshore). Around $36^{\circ} \mathrm{S}$ the wide Itata Canyon interrupts the continental shelf. South of this canyon the shelf widens to 50 nautical miles (Itata terrace) and it is interrupted again by the narrow but deep Bio-bio Canyon at $36.9^{\circ} \mathrm{S}$. Coastline orientation changes sharply at $37.1^{\circ} \mathrm{S}$, forming the Gulf of Arauco, and causing a $90^{\circ}$ local divergence of the coast and isobath at the flanking eastern point (Punta Lavapie; Fig. 1). During the spring-summer period, high salinity (34.5), low oxygen $\left(<1 \mathrm{ml} \mathrm{l}^{-1}\right.$ ) and high nutrient Equatorial Sub-Surface Waters (ESSW), shoal over the continental shelf in this area (Djurfeldt 1989). These waters are considered responsible for the coastal fertilization that sustains one of the most productive coastal areas in the world's oceans (Daneri et al. 2000). A strong influence of topographical and geographical features on the upwelling process in this area has been described (Sobarzo \& Djurfeldt 2004) and modelled (Mesias et al. 2003).

Target species. We chose for our analysis 5 species (groups) of crustacean larvae because of their contrasting characteristics regarding adult habitat depth range. Additionally, they were well represented in the plankton samples. They differ in number of larval stages but details of their reproductive and larval ecology are not well known. Adult Emerita analoga and Blepharipoda spinimana reside in intertidal sandy bottoms. E. analoga has a long larval development (several months depending on water temperature) and, although ovigerous females are found year round, 2 main hatching periods occur during austral spring and late summer (Contreras et al. 1999). There is no information on the timing of $B$. spinimana larval devel- opment, and we identified 4 larval stages. The majid Libidoclaea granaria, with 2 zoeal stages (Faguetti 1969), was selected from below $100 \mathrm{~m}$ depth. Its larval development is shorter than that of $E$. analoga (about a month at $15^{\circ} \mathrm{C}$ ). Neotrypaea uncinata and pagurids inhabit subtidal bottoms, have 5 and 4 stages respectively, and longer larval development than L. granaria. At ambient temperature they developed through their last zoea stage in between 40 to 50 d (Aste 1982, Lavados 1982).

Sampling. During 7 to 13 November 2001 and 7 to 12 March 2002 we conducted hydrographic and zooplankton sampling over the continental shelf of Central Chile between 35 and $37^{\circ} \mathrm{S}$. The hydrographic survey consisted of a total of 69 profiles, in 11 equally spaced transects (I through XI; Fig. 1). Along each transect the stations were numbered 1 to 6 (or 7) from the coast to the ocean. Exceptionally bad weather conditions hindered the completion of some of the planned casts (e.g. Transect VIII: Stns 1, 2 and 3). Distance between stations was approximately 5 nautical miles, and began at approximately 2 to 3 nautical miles from shore. Hydrographic casts were undertaken with a Neill Brown Mark III CTDO (November cruise) and a SeaBird SBE-25 (March cruise). Sampling was conducted throughout the 24 hour day. Stratified zooplankton samples (oblique tows) were taken with a tucker trawl sampling gear. The net had a $1 \mathrm{~m}^{2}$ frame, a $300 \mu \mathrm{m}$ mesh size and it was equipped with a calibrated General Oceanic flow meter. The vessel navigated at approximately 2 knots during tucker trawl deployment. Cable length was adjusted according to the desired depth and the angle between the cable and the vertical. In the northern zone of our sampling area (from 36 to $35^{\circ} \mathrm{S}$ ), strata were 0 to 50,50 to 100,100 to 150,150 to $250 \mathrm{~m}$ depending on the station depth. In the southern area, vertical resolution was higher, and we took samples every $25 \mathrm{~m}$ down to $100 \mathrm{~m}$, and every $50 \mathrm{~m}$ in the deeper layer depending on station depth. The definition of strata to be sampled resulted from a compromise between cruise time and information to be gathered. Based on previous cruises in the area it was known that water properties usually show stronger vertical gradients in the southern sampled area, and therefore a more intensive sampling regarding vertical resolution should be conducted there. Samples were fixed in buffered formalin (10\%) and brought to the laboratory for identification and counting. Winds for the period were obtained from Carriel Sur Airport of Concepción (36 46' 22" S, $\left.73^{\circ} 03^{\prime} 47^{\prime \prime} \mathrm{W}\right)$.

The selected crustacean larvae from Transects III and V through XI were sorted and identified from the November 2001 cruise, and from Transects III, V, VII, X 
and XI from the March 2002 cruise. Using stereomicroscopy, Neotrypaea uncinata stages were identified following Aste (1982), pagurids following Lavados (1982), and Libidoclaea granaria following Faguetti (1969). The species Blepharipoda spinimana was identified following Concha (1978) and the stages were classified based on our own inventory. Emerita analoga was sorted into stages following Johnson \& Lewis (1942).

Data analysis. In order to reveal oceanographic features taking place during the sampling period, we constructed horizontal maps of temperature and salinity. Wind data for the period were used to estimate the Ekman transport $\left(U_{E}\right.$ in $\left.\mathrm{m}^{2} \mathrm{~s}^{-1}\right)$ following Gill (1982):

$$
U_{E}=\frac{Y_{s}}{\rho_{W} f}
$$

where $Y_{s}=$ along-shore wind stress, $\rho_{W}=$ water density $\left(1025 \mathrm{~kg} \mathrm{~m}^{-3}\right)$, and $f=$ Coriolis parameter $=-8.69 \mathrm{E}^{-5}$ $\left.\mathrm{s}^{-1}\right)$.

Larval numbers were first standardized according to the volume filtered by each net and then the number of individuals per $100 \mathrm{~m}^{3}$ was multiplied by the depth of the corresponding stratum to obtain the number of individuals per $100 \mathrm{~m}^{2}$ within each stratum. They were also integrated down to the maximum sampled depth at each station to construct horizontal distribution maps. Due to the patchy distribution of plankton, surveys are characterized by a large proportion of 0 counts and few high values, therefore, means of each stage density, variance of the mean estimate and variance over the sampled area were calculated based on a delta distribution (Pennington 1983). Stage abundance within each species should provide a gross estimate of their main hatching period.

Three analyses of spatial distribution were performed in order to summarize and compare stages/ species spatial information: (1) The spreading of larvae in the sampled area was analysed through the percentage of positive stations out of the total analysed in each cruise. (2) In spite of the availability in the literature of several patchiness indexes developed by terrestrial ecologists and/or data counts, their applicability in plankton density data is not straightforward (Bez 2000). Therefore, in order to reveal the degree of clumping in the stages/species variable in this study, and to be able to compare among stages and species, we calculated the coefficient of variation (CV: $\mathrm{SD} / \mathrm{mean}$ ) based on the delta distribution. This index was calculated for the March cruise when most species and stages were in large enough quantities to allow comparisons. (3) Across-shore distribution in each transect was analyzed with the weighted mean offshore distance $(O D)$ in each transect:
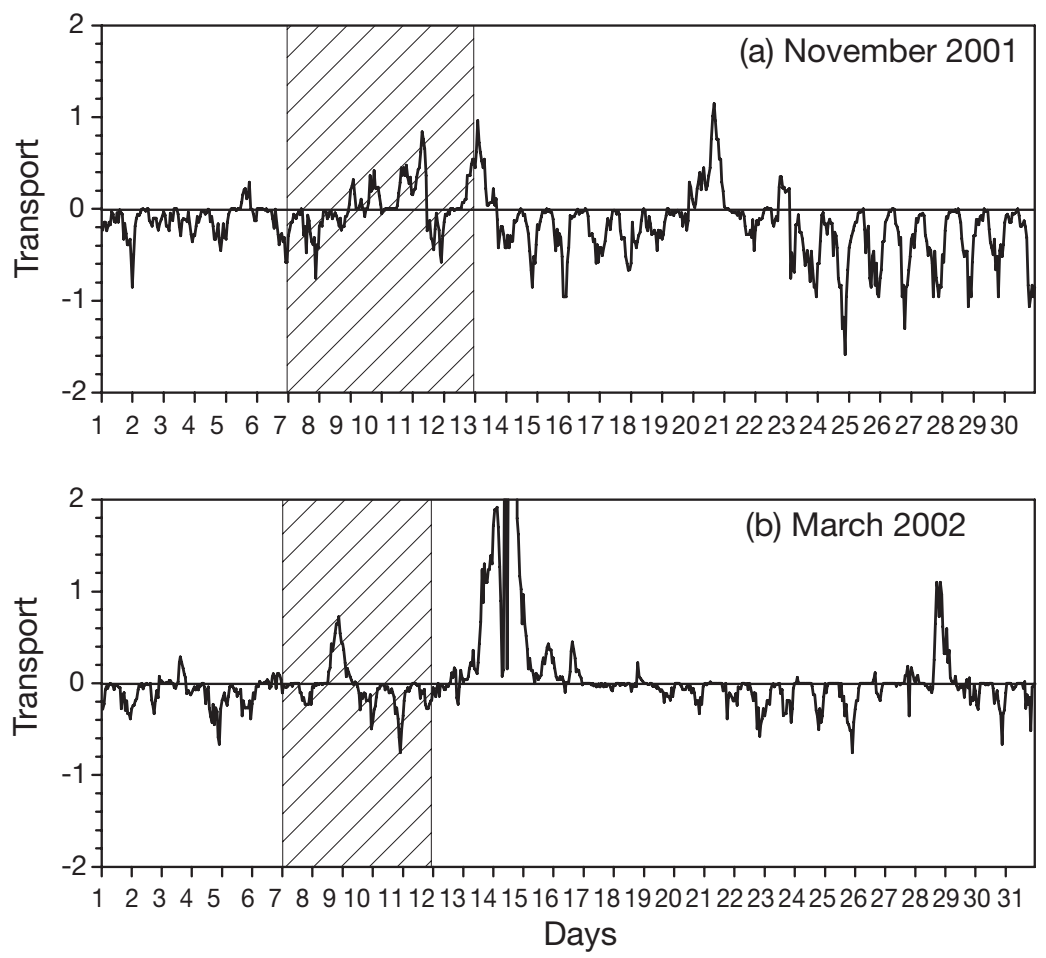

Fig. 2. Ekman transport $\left(\mathrm{m}^{2} \mathrm{~s}^{-1}\right)$ : (a) November 2001, (b) March 2002. Box shows the date of the hydrographic cruises. Negative values indicate offshore transport resulting from upwelling

$$
O D=\frac{\sum d_{i} \times n_{i}}{N}
$$

where $d_{i}$ is the distance offshore of Stn $i$, $n_{i}$ is the integrated number of organisms at $\operatorname{Stn} i$, and $N$ is the total number of organisms in the transect $\left(\sum n_{i}\right)$.

In order to characterize the vertical distribution of larvae, we calculated the mean weighted depth $(M D)$ distribution (also called 'centroid') for each group of organisms at each station as:

$$
M D=\frac{\sum p_{k} \times z_{k}}{\sum p_{k}}
$$

where $p_{k}$ is the number of organisms at stratum $k$, and $z_{k}$ is mean depth of stratum $k$. Additionally, the across-shore modal position was registered for each group. Plots of mean weighted depth $(M D)$ for each stage for day and night were calculated. Day and night differences were analysed in the following way: when $M D$ was significantly correlated with station depth we carried out analysis of covariance on $M D$ for the 
factor day and night, with maximum station depth as a covariate (separate or homogeneous slopes depending on parallelism). When such a correlation was not found, a $t$-test for independent samples was applied. Whenever variance was heterogeneous (Levene test), t-test with independent variances was applied. We also compared overall species depth distribution (MD) with Kruskal-Wallis analysis of variance and Mann-Whitney $U$-test to compare paired samples. Both temperature and oxygen concentration at $M D$ for each species (all stages pooled) were obtained. The frequency of centroids occurring within certain temperature and oxygen ranges was calculated and the cumulative percentage frequency as a function of temperature and oxygen was used to characterize the environment for each species.

\section{RESULTS}

\section{Meteorological forcing and general along-shore hydrographic conditions}

Just before the November cruise and during the first $2 \mathrm{~d}$ (sampling Transects I through III), southerly winds were moderately favourable for upwelling. Later, while sampling Transects V, VI and VII over the Itata Canyon: Transects V, VI and VII, winds changed to northerly (favouring downwelling), and they were later only interrupted by $1 \mathrm{~d}$ of southerly winds (sampling of Transects X and XI).

During March 2002 wind was again mildly favourable for upwelling during the week before and during the cruise, with only 2 reversals of $1 \mathrm{~d}$ (sampling Transects IV and V, and the end of Transect XI; Fig. 2).

During November 2001, temperature at $10 \mathrm{~m}$ depth was colder than in March 2002 with an upwelling event in the northern region (Transects I, II and III) and a coastward intrusion of warmer oceanic water over the Itata canyon (Transects V, VI and VII; Fig. 3a). Coastal upwelling at the north of the Itata Canyon was evidenced by a colder $\left(11\right.$ to $12^{\circ} \mathrm{C}$ ) and saltier (34.4 to 34.5) coastal band of water typical of Equatorial SubSurface Waters (ESSW). Higher surface temperatures (around $13^{\circ} \mathrm{C}$ ) associated with lower salinities (34) dominated the Itata terrace at the south of the Itata Canyon. On this shelf the base of the thermocline was located between 40 and $60 \mathrm{~m}$ depth (not shown). The base of the thermocline within the Itata canyon $\left(10.5^{\circ} \mathrm{C}\right.$ isotherm) was found at around $100 \mathrm{~m}$ depth (Transects VI and V). Larger horizontal gradients of temperatures appeared at the head of the Itata canyon and northward of this canyon. The Itata terrace was more homogenous and across-shore temperature gradients almost vanished. The freshest surface water was found in the south related to fresh water runoff from the Biobio river. In the deeper layer the contours of salinity and oxygen closely followed the bottom topography showing the intrusion of ESSW into the Bio-bio and the Itata Canyons (not shown).

During March 2002, all coastal regions showed cold waters $\left(11\right.$ to $\left.12^{\circ} \mathrm{C}\right)$ and salinities around 34.4 to 34.5 . In the north, the strongest onshore-offshore surface 
Table 1. Neotrypaea uncinata, Libidoclaea granaria, Emerita analoga, pagurids and Blepharipoda spinimana. Abundance and distribution of larval stages in south central Chile continental shelf during November 2001 and March 2002. PS: proportion of positive stations out of the total sampled during each cruise; Mean: mean number of individuals integrated $100 \mathrm{~m}^{-2}$; Var mean: variance of the mean estimate; Var: variance; CV: coefficient of variation

\begin{tabular}{|c|c|c|c|c|c|c|c|c|c|c|}
\hline \multirow[t]{2}{*}{ Species } & \multirow{2}{*}{ Stage } & \multicolumn{3}{|c|}{ — November 2001} & \multirow[b]{2}{*}{ Var } & \multicolumn{4}{|c|}{ - March 2002} & \multirow[t]{2}{*}{$\mathrm{CV}$} \\
\hline & & PS & Mean & Var mean & & PS & Mean & Var mean & Var & \\
\hline \multirow[t]{5}{*}{ N. uncinata } & I & 0.69 & 556 & 41600 & 3837988 & 0.53 & 236 & 10841 & 393270.2 & 2.66 \\
\hline & II & 0.53 & 922 & 150300 & 13665233 & 0.60 & 4620 & 9219800 & $6.36 \mathrm{E}+08$ & 5.46 \\
\hline & III & 0.49 & 450 & 38000 & 3382600 & 0.60 & 2156 & 1964635 & $1.32 \mathrm{E}+08$ & 5.33 \\
\hline & IV & 0.58 & 385 & 32300 & 2714652 & 0.47 & 549 & 54591 & 1840836 & 2.47 \\
\hline & $\mathrm{V}$ & 0.53 & 606 & 89000 & 10083285 & 0.43 & 134 & 2948 & 95289.12 & 2.30 \\
\hline \multirow[t]{2}{*}{ L. granaria } & I & 0.89 & 1580 & 318000 & 31294697 & 0.60 & 93 & 733 & 23063.31 & 1.63 \\
\hline & II & 0.33 & 50 & 500 & 44363.96 & 0.67 & 219 & 2983 & 92686.18 & 1.39 \\
\hline \multirow[t]{5}{*}{ E. analoga } & I & 0.56 & 212 & 5100 & 437204.5 & 0.93 & 12164 & 31825190 & $1.8 \mathrm{E}+09$ & 3.49 \\
\hline & II & 0.09 & 23 & 280 & 35513.76 & 0.87 & 2418 & 1025250 & 47546913 & 2.85 \\
\hline & III & 0.07 & 14 & 130 & 18473.15 & 0.87 & 804 & 47471 & 1616605 & 1.58 \\
\hline & IV & 0.31 & 19 & 300 & 1346.1 & & 1379 & 49921.52 & 1551264 & 0.90 \\
\hline & $\mathrm{V}$ & 0.80 & 173 & 1400 & 87053.06 & 0.87 & 330 & 9415 & 332048.6 & 1.75 \\
\hline \multirow[t]{5}{*}{ Pagurids } & I & 0.16 & 26 & 200 & 14490.84 & 0.30 & 87 & 1825 & 57944.91 & 2.77 \\
\hline & II & 0.24 & 46 & 400 & 33168.01 & 0.60 & 1218 & 296633 & 11546060 & 2.79 \\
\hline & III & 0.76 & 262 & 3100 & 180570.7 & 0.60 & 1847 & 752135 & 30605569 & 3.00 \\
\hline & IV & 0.22 & 78 & 1600 & 120668.7 & 0.57 & 1196 & 304063 & 11768648 & 2.87 \\
\hline & M & 0.13 & 8 & 10 & 1086.838 & 0.53 & 269 & 11645 & 399152.2 & 2.35 \\
\hline \multirow[t]{4}{*}{ B. spinimana } & $\mathrm{I}$ & 0.13 & 20.3 & 141.8 & 9678.26 & 0.37 & 322 & 32145 & 1166296 & 3.35 \\
\hline & II & 0.04 & & & & 0.50 & 313 & 19331 & 685053.3 & 2.64 \\
\hline & III & 0.07 & 5.6 & 18 & 1234.986 & 0.53 & 324 & 20177 & 729336.8 & 2.64 \\
\hline & IV & 0.02 & & & & 0.57 & 329 & 17415 & 610974.2 & 2.38 \\
\hline
\end{tabular}

temperature gradients occurred. Warm waters were found offshore and surface salinity showed the influence of Rio Maule. The base of the thermocline was
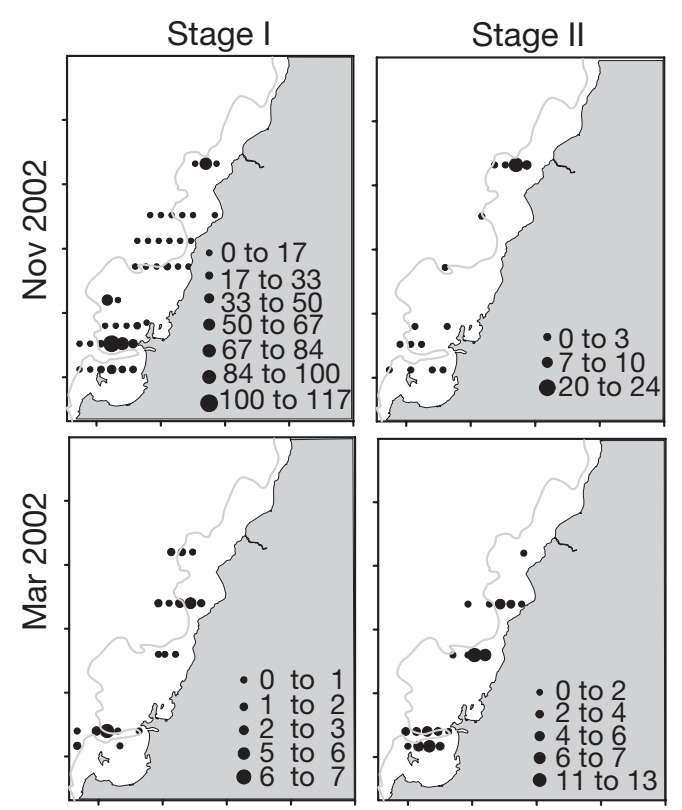

Fig. 4. Libidoclaea granaria. Spatial distribution of larval Stages I and II. Numbers are in individuals integrated $\mathrm{m}^{-2}$ located at about $60 \mathrm{~m}\left(11.5^{\circ} \mathrm{C}\right.$ isotherm $)$ in the north, shallower over the Itata terrace at Transect VII (20 to $25 \mathrm{~m}$ depth), and deeper in the Itata Canyon (Transects VI and V, $50 \mathrm{~m}$ ). Again, a coastward intrusion of warmer surface waters $\left(15\right.$ to $\left.16^{\circ} \mathrm{C}\right)$ with salinities near to 34.2 appeared related with the Itata canyon.

\section{Abundance and stage composition}

Overall species abundance was larger in March than in November, except for Libidoclaea granaria. L. granaria showed a marked peak in Stage I abundance during November, while it was $<10$-fold lower in March (Table 1, Fig. 4). In March, Stage II larvae comprised $2 / 3$ of the total L. granaria collected, indicating that major spawning occurred during spring (Table 1). Overall abundance of Emerita analoga was 100-fold larger in March than in November. Stages I and V were dominant during November while intermediate stages were scarce. During March, zoea I by itself far outnumbered all other present stages/species, indicating a peak larval release during late austral summer (Table 1, Fig. 5).

Intermediate stages of Neotripaea uncinata and pagurids were more abundant than early and late stages during both seasons. Larger quantities of larvae 

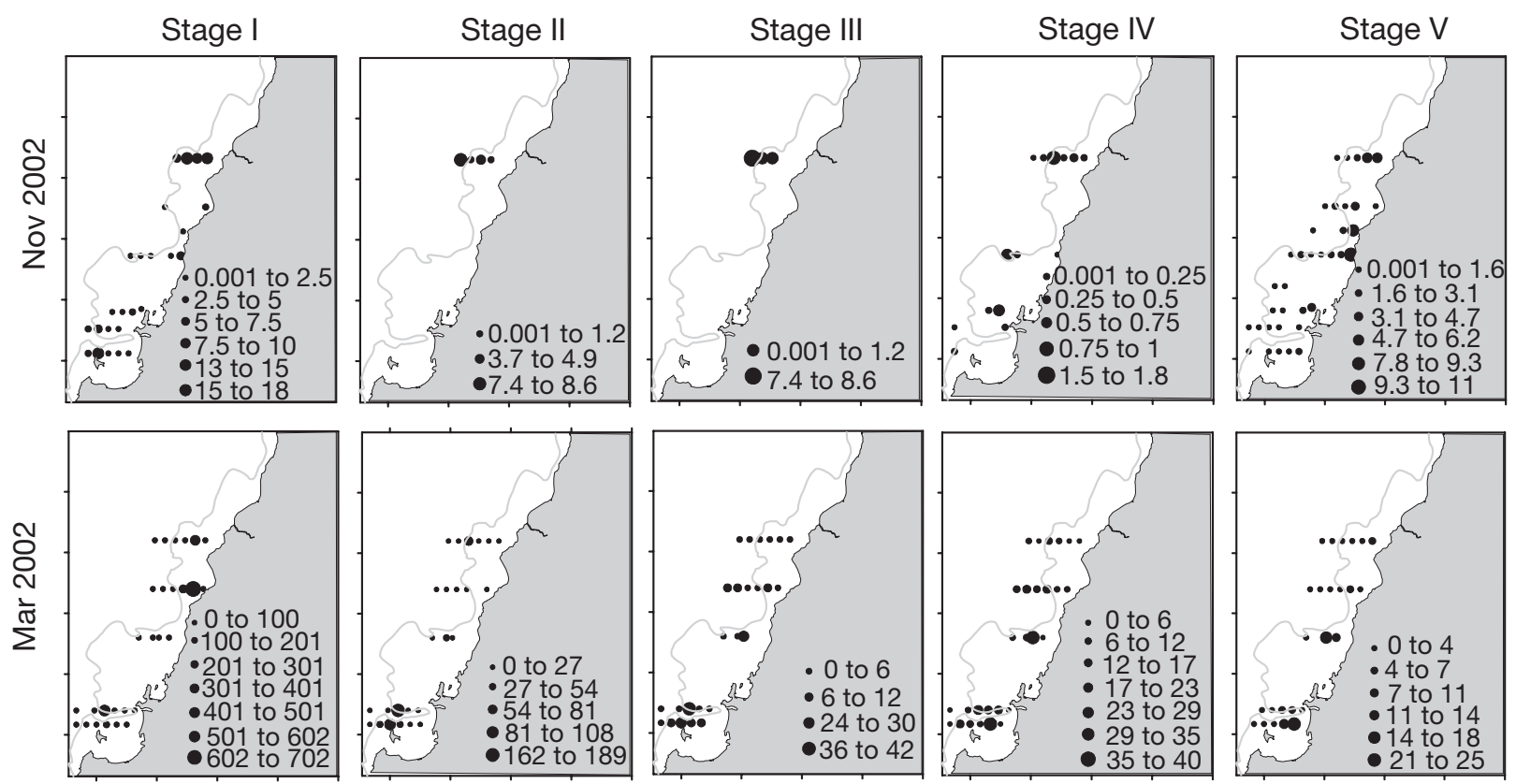

Fig. 5. Emerita analoga. Spatial distribution of larval Stages I to V. Numbers are in individuals integrated $\mathrm{m}^{-2}$
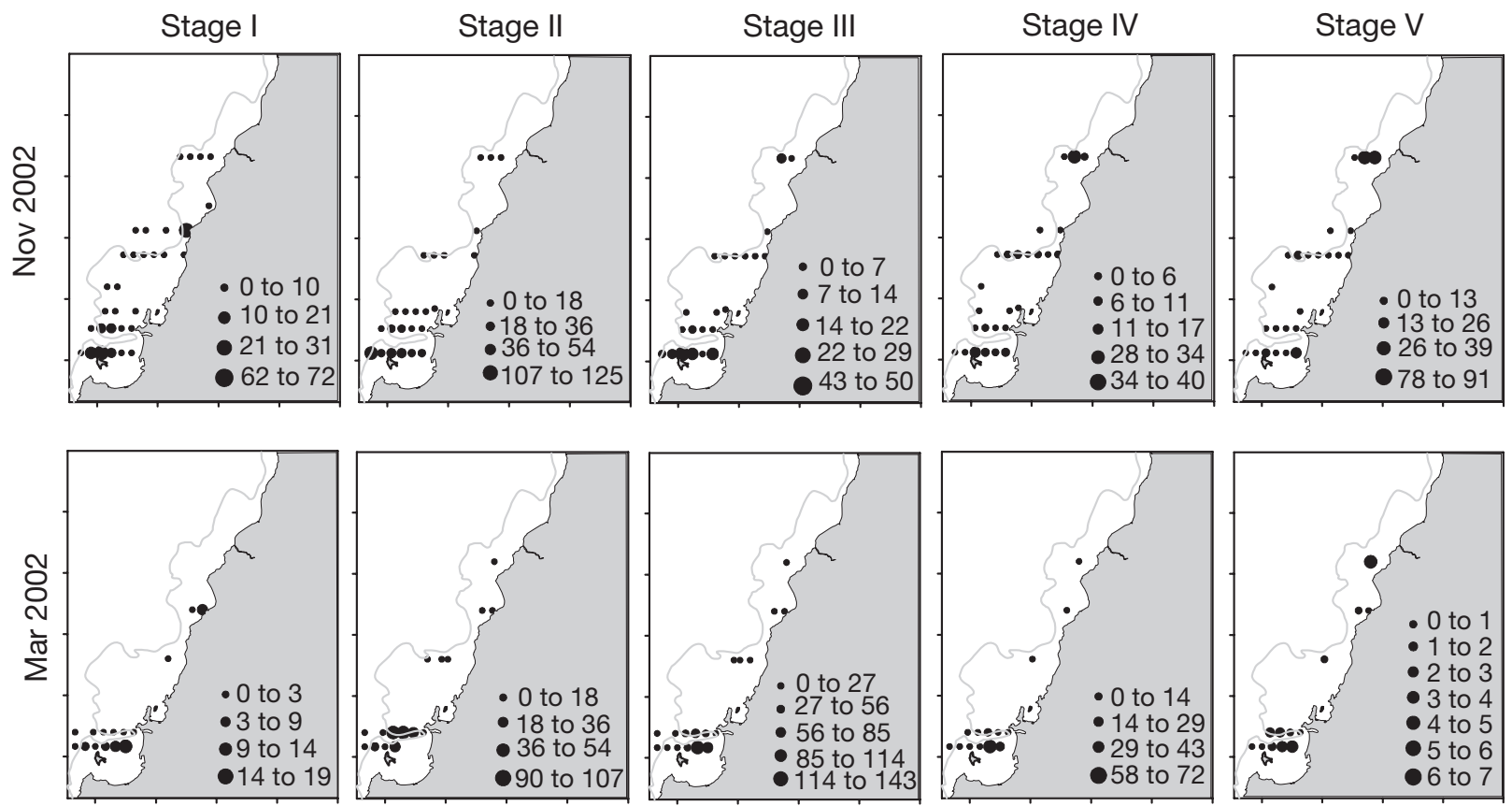

Fig. 6. Neotrypaea uncinata. Spatial distribution of larval Stages I to V. Numbers are in individuals integrated $\mathrm{m}^{-2}$

of both species were found in March, suggesting peak larval release during summer (Table 1, Figs. 6 \& 7). The same is suggested for Blepharipoda spinimana, it was barely present in November while in March there was an even distribution of younger and older stages (Table 1, Fig. 8).

November and March percentages of positive samples $(P S)$ occupied by each stage were not linearly correlated 

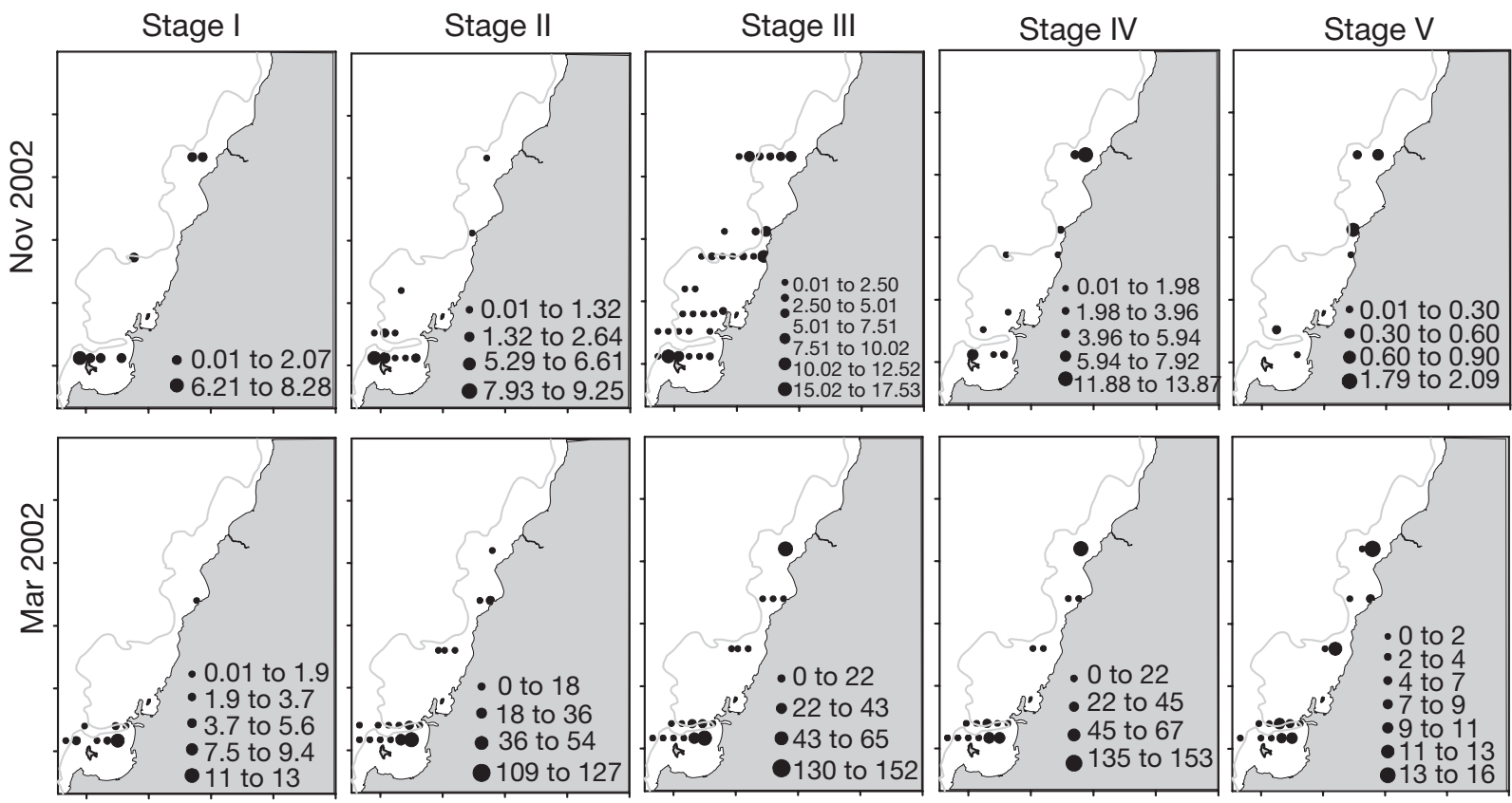

Fig. 7. Pagurids. Spatial distribution of larval Stages I to IV and megalopas. Numbers are in individuals integrated $\mathrm{m}^{-2}$
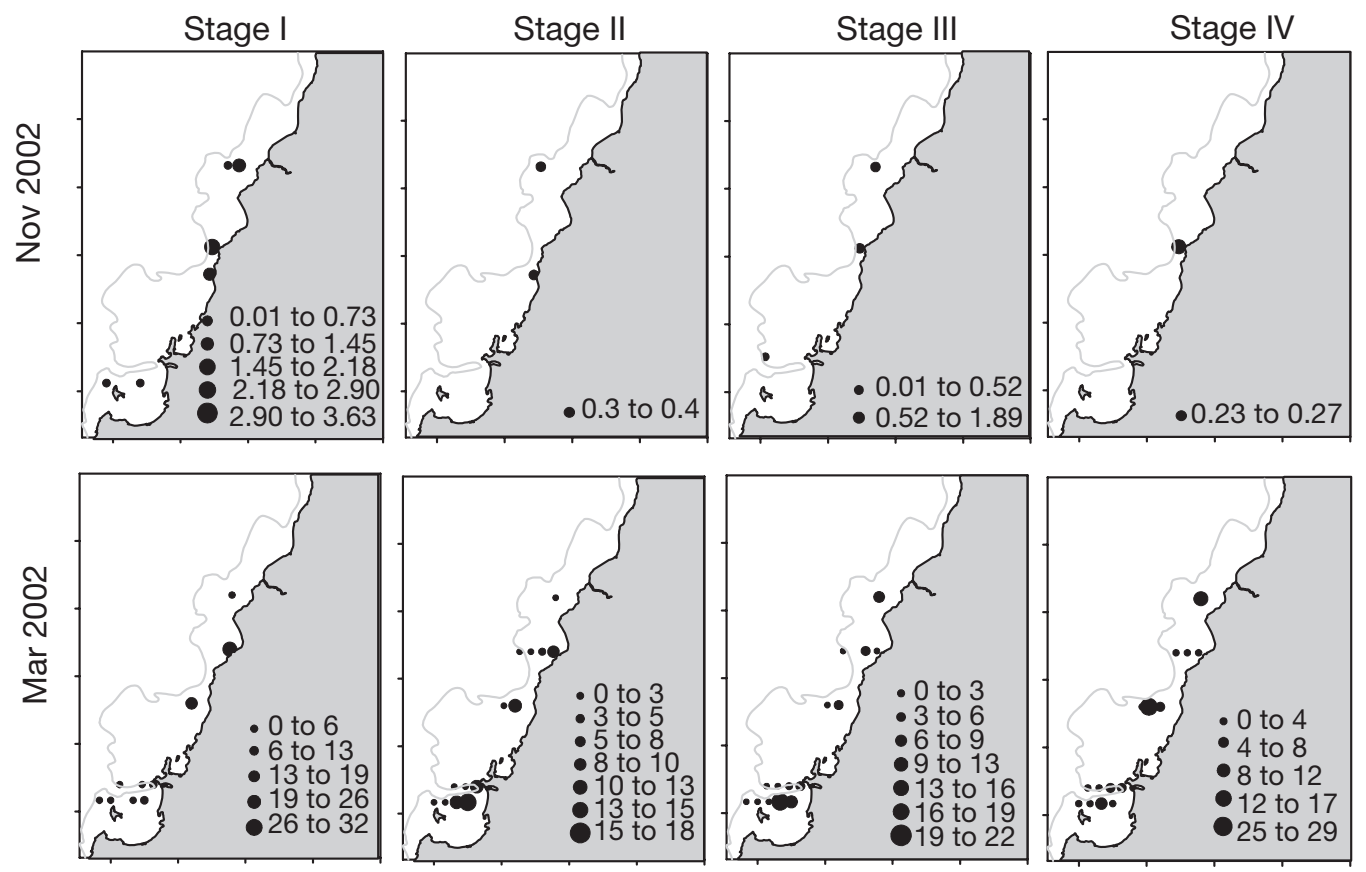

Fig. 8. Blepharipoda spinimana. Spatial distribution of larval Stages I to IV. Numbers are in individuals integrated $\mathrm{m}^{-2}$

to larval abundance (mean individuals $100 \mathrm{~m}^{-2}$ ). Very low $P S$ co-occurred with very low numbers of organisms, however, large $P S$ occurred over a wide range of abundances both inter and intra-specifically.

In November 2001, the more widespread distribution was that of Libidoclaea granaria I $(P S=0.89)$, followed by Emerita analoga V and pagurids III (Table 1, Figs. 4, 5 \& 7). Neotrypaea uncinata showed intermediate $P S$ (from 0.49 to 0.69) and Blepharipoda spinimana was circumscribed to a few (coastal) stations ( $P S=0.02$ to 0.13; Fig. 8). During March, all stages of E. analoga were more widespread than the other groups (PS 
above 0.85), followed by L. granaria. As in November, B. spinimana occurred at the fewest stations without changes in abundance from stage to stage (Table 1).

During March, Libidoclaea granaria and Emerita analoga showed the least heterogeneous spatial distribution (as denoted by the lower overall coefficient of variation, Table 1). However, E. analoga showed marked contrasts between stages, the coefficient of variation decreased from Stage I to IV and increased again at Stage V. Blepharipoda spinimana and L. granaria also spread out with increasing stages. In contrast, pagurids and Neotrypaea uncinata showed higher aggregation at intermediate stages (Table 1).

\section{Across-shore distribution}

During both cruises, most larvae were found at or coastward of Stn 3 in the northern area (except Emerita analoga). During March 2002, some Stage II Libidoclaea granaria were spread offshore in this area. During November, in the central area, L. granaria was found along the entire Transect $\mathrm{V}$ and further offshore at Transect VII (Fig. 4). Blepharipoda spinimana peaked at the coastal stations (Transects V, VI and VII) (Fig. 8). E. analoga, Neotrypaea uncinata and pagurids also peaked at the coast at the transects over the Itata Canyon but spread offshore in Transect VII (Figs. 5-7). During March 2002, in contrast, all groups OD over Transect VII were shifted coastward compared to November (Fig. 9). In the south, transects at the northern and southern flanks of the Bio-bio Canyon (X and $\mathrm{XI})$ were sampled under upwelling favourable winds and the beginning of a reversal during both cruises. During November, E. analoga, pagurids, B. spinimana and $N$. uncinata ODs ranged from 3 to 4.5 (offshore, compared to the northern region). L. granaria in contrast, was more concentrated towards the coast. During March, ODs at Transects X and XI were offshore with respect of those in other transects (Figs. 4-8).

Overall, Emerita analoga, pagurids, Blepharipoda spinimana and Neotrypea uncinata (except Stage II) were distributed further offshore in the southern area compared to the north and Itata Canyon areas. Libidoclaea granaria, instead, was farther offshore at the Itata Canyon (sampled during downwelling winds), and approached the coast in the north and south (sampled during upwelling winds in November). E. analoga Stage I and $\mathrm{V}$ concentrated closer to the shore than intermediate stages (Fig. 9). Late stages N. uncinata, L. granaria and pagurids approached the coast with increasing stages, however, across-shore range was more restricted during March (Fig. 9). During both cruises B. spinimana was the species closest to shore, while L. granaria and E. analoga were the furthest offshore.

\section{Depth range distribution}

During November 2001, Neotrypaea uncinata Stages II, III and V were significantly deeper during the day than during the night (Fig. 10). Stages I and IV showed no significant differences in depth distribution
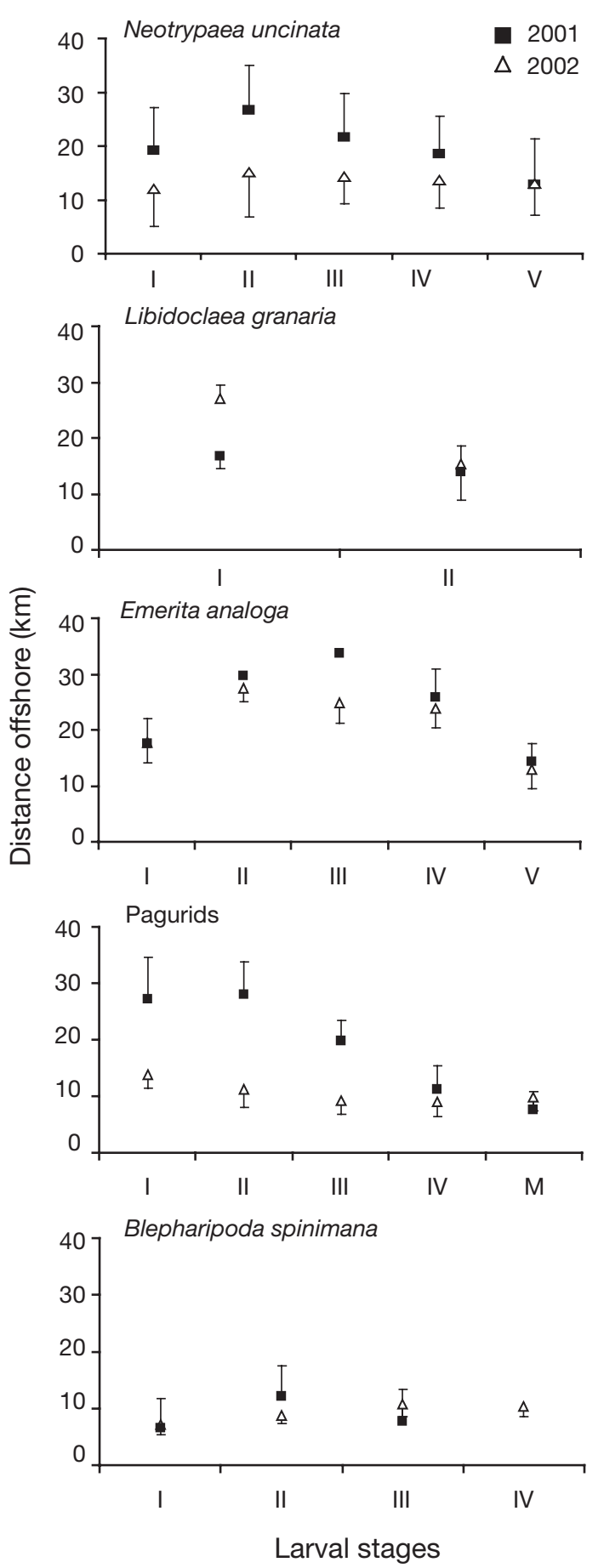

Fig. 9. Mean distance offshore + or -1 SD for each stage of the 5 studied species 
(Table 2). Only Emerita analoga Stages I, IV and V were analyzed during November 2001 because of the low number of positive stations of the other stages, and there were no significant differences for day or night mean depth distribution in any of these 3 stages. The same was true for Libidoclaea granaria Stages I and II. pagurids were deeper in the water column during daytime, but differences were significant only for Stage IV (ANCOVA, Table 2). E. analoga distributed significantly shallower than L. granaria, pagurids and $N$.

Nov 2001
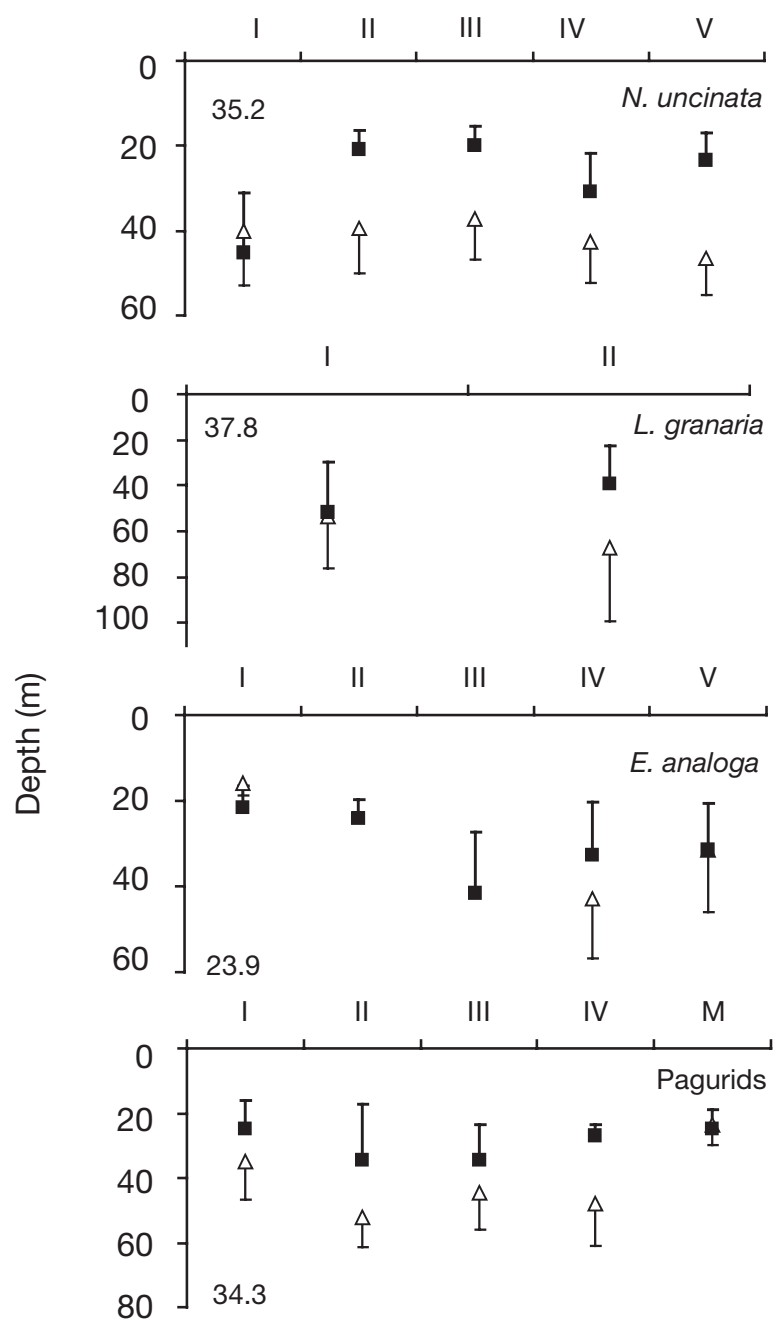

Night

$\triangle$ Day

Fig. 10. Mean day and night depth distribution of larval stages of the 5 studied species. Vertical lines indicate one half SD. Large numbers given in each graph correspond to the overall species mean depth during each cruise uncinata (Kruskal-Wallis for factor species, and Mann-Whitney $U$-test for pair comparisons, p < 0.01). Blepharipoda spinimana was not considered since it occurred in very few stations.

In November, as shown by the cumulative percent frequency of $M D$ occurrence at temperature/oxygen concentration (Fig. 11), more than $50 \%$ of Neotrypaea uncinata, pagurids and Libidoclaea granaria centroids occurred at temperatures below $11^{\circ} \mathrm{C}$ and oxygen levels lower than $1 \mathrm{ml} \mathrm{l}^{-1}$ which characterize ESSW. In

\section{Stages}
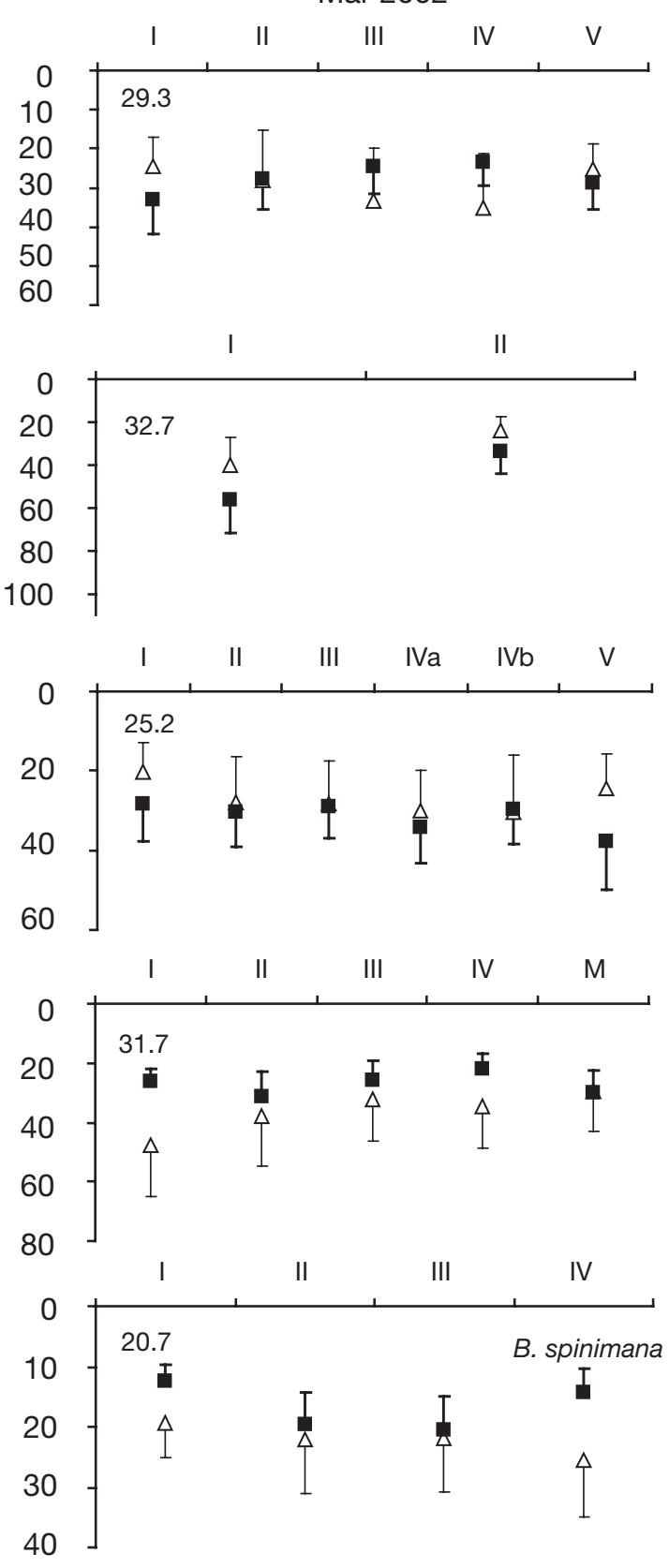
Table 2. Summary of analysis comparing day and night mean depth of each species stage. Dependence: mean depth dependence on station depth (linear regression). Parallelism: when the day and night mean depth depended on station depth, the parallelism for regression lines for day and night samples. CoVar: analysis of covariance, performed if dependence and parallelism were significant. $t$-test: between day and night samples when covariance analysis was not proper or could not be performed. ns $=$ not significant, ${ }^{*}$ significant at $\alpha=0.05,{ }^{* *}$ significant at $\alpha=0.01$

\begin{tabular}{|c|c|c|c|c|c|c|c|c|c|}
\hline \multirow[t]{2}{*}{ Species } & \multirow[t]{2}{*}{ Stage } & \multicolumn{4}{|c|}{ 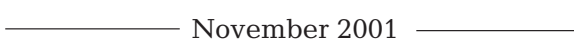 } & \multicolumn{4}{|c|}{ March 2001} \\
\hline & & Dependence & Parallelism & CoVar & $t$-test & Dependence & Parallelism & CoVar & $t$-test \\
\hline \multirow[t]{5}{*}{ N. uncinata } & I & $\mathrm{ns}$ & & & ns & ns & & & ns \\
\hline & II & * & $\mathrm{ns}$ & & $* *$ & $\mathrm{~ns}$ & & & ns \\
\hline & III & * & ns & & $* *$ & ns & & & ns \\
\hline & IV & ns & & & $* *$ & ns & & & ns \\
\hline & $\mathrm{V}$ & ${ }^{*}$ & ns & & $* *$ & ns & & & ns \\
\hline \multirow[t]{2}{*}{ L. granaria } & I & $\mathrm{ns}$ & & & ns & * & * & ns & \\
\hline & II & ns & & & ns & * & * & ns & \\
\hline \multirow[t]{5}{*}{ E. analoga } & I & $\mathrm{ns}$ & & & ns & $\mathrm{ns}$ & & & ns \\
\hline & II & & & & & ns & & & ns \\
\hline & III & & & & & ns & & & ns \\
\hline & IV & ns & & & ns & ns & & & ns \\
\hline & $\mathrm{V}$ & ns & & & ns & ns & & & ns \\
\hline \multirow[t]{4}{*}{ Pagurids } & I & & & & & * & * & ns & \\
\hline & II & ns & & & ns & * & * & ns & \\
\hline & III & ns & & & ns & $*$ & * & ns & \\
\hline & IV & $*$ & * & * & & * & $*$ & ns & \\
\hline \multirow[t]{4}{*}{ B. spinimana } & I & & & & & * & ns & & ns \\
\hline & II & & & & & * & ns & & ns \\
\hline & III & & & & & ns & & & ns \\
\hline & IV & & & & & ns & & & ns \\
\hline
\end{tabular}

contrast, Emerita analoga, the shallowest species, occurred mainly above $3 \mathrm{ml} \mathrm{l}^{-1}$ and above $11^{\circ} \mathrm{C}$.

During March 2002, Neotrypaea uncinata and pagurids showed the same trend as in the November cruise (shallower position during nighttime except $N$. uncinata Stage I) although differences were not significant (Table 2). During March, not only were fewer stations considered in the analysis but it coincided that shallower stations were sampled during daytime. The mean weighted species depth showed that Blepharipoda spinimana was the shallowest followed by Emerita analoga and that Libidoclaea granaria was the deepest.

\section{DISCUSSION}

\section{Larval distribution: topography and upwelling phase}

Different patterns of across-shore larval distribution were observed among areas and species. In the northern area, where upwelling was circumscribed over the narrow shelf most species of crustacean larvae were concentrated between the coast and the shelf break, offshore the marked temperature gradient that coincided with the shelf break few larvae were found. The species located nearshore were those that were mainly released during summer, and/or displayed vertical migrations. Surface dwelling larvae (Emerita analoga) and early stages of deeper released larvae (Libidoclaea granaria), were not circumscribed to coastal stations in this oceanographic setting. These are expected pat-

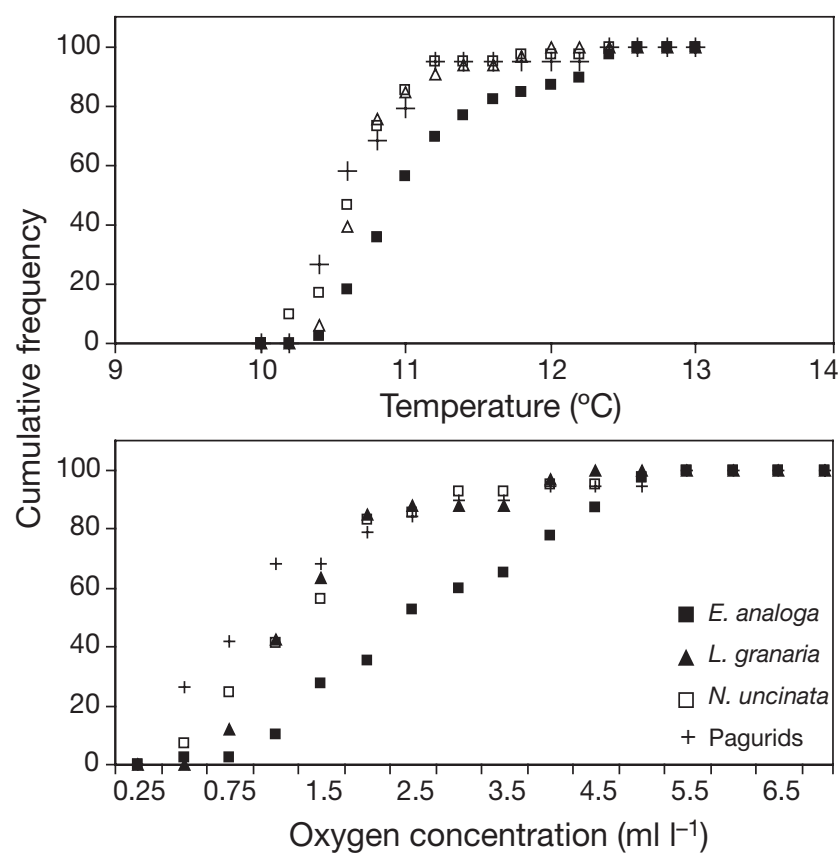

Fig. 11. Cumulative frequency of centroids for temperature and oxygen concentration 
terns of across-shore distribution in a coastal upwelling area (Peterson et al. 1979). During both cruises in the southern area larvae were widespread between the coast and the offshore stations with maximums at intermediate distance from shore, in spite of the same prevailing, upwelling winds found in the north. Evidence from direct current measurements (Atkinson et al. 2002, Valle-Levinson et al. 2003), modelling simulations (Mesias et al. 2001) and surface advection (Navarro et al. 2004) indicate that recirculation features develop at the Gulf of Arauco area as a consequence of coastal geometry. These recirculation features could have the potential for retaining organisms over the shelf, even during upwelling winds, although not necessarily at the coast. Large concentrations of plankton have been repeatedly reported in the gulf of Arauco/Bio-bio area (Castro et al. 1993, 2000, Yannicelli et al. 2006), as well as high levels of production (Daneri et al. 2000) diminishing mainly offshore the shelf break. In this area, there were not conspicuous differences between the horizontal larval distributions of the different species, probably indicating that local circulation might have disrupted any potential inshore-offshore gradient over this part of the shelf.

In the central area (Itata Canyon) when warmer surface waters were closer to the shore during downwelling, larval peaks occurred at the coastal station, except Libidoclaea granaria larvae, that were distributed deeper and offshore. To the south of the Canyon (Transect VII) most groups spread offshore during downwelling in November, but remained closer to the coast during upwelling in March. These alternating situations were evident for all taxa, and differed from our expectations, especially the downwelling situation for vertically migrating and surface larvae that should have been concentrated at the coast. However, the modelling of coastal upwelling process between 38 and $35^{\circ} \mathrm{S}$ indicates that a strong equatorward jet develops and meanders along the shelf break north of Punta Lavapie, shedding eddies at about $36^{\circ} \mathrm{S}$ (Mesias et al. 2003). In our study, a northward flow along the shelf break would bend coastward at the Itata Canyon during November (as inferred from the geopotential anomalies and geostrophic calculations: Sobarzo et al. 2004, Yannicelli 2005). Thus, if organisms are entrained into these types of features, their acrossshore distribution would not respond directly to upwelling/downwelling dynamics.

\section{Larval distribution and species ecology}

Libidoclaea granaria larvae were mainly released during spring, the period of intensified upwelling. $L$. granaria occupies the continental shelf in south-central
Chile, and usually turns up as bycatch of the squat lobster Pleuroncodes monodon fishery trawling at depths around $100 \mathrm{~m}$. This seasonal timing of larval release also appears to coincide with that of $P$. monodon (Palma \& Arana 1997). There is very little information regarding larval distribution of crustaceans whose adults inhabit depths around $100 \mathrm{~m}$, and their association with upwelling cycles. For larvae released over the shelf area, the upwelling season might imply onshore transport, and enhanced feeding conditions. The facts that zoea I appeared widely distributed (especially during downwelling winds) and zoea II approached the coast (especially during upwelling) support this idea. Across-shore distribution was apparently accomplished by occupying deeper waters than the other species and without displaying diel changes in their vertical position. In fact, mean depth was strongly associated with station depth, and a large proportion of larvae occurred in low oxygen ESSW. In a spatially limited study, L. granaria larvae had been reported in deep intruding waters in the gulf of Arauco during upwelling conditions (Yannicelli et al. 2006). These results are in agreement with Garland et al. (2002), who showed that larvae of deep dwelling benthic adults could be transported shoreward in subsurface waters during upwelling conditions over the continental shelf. Similar patterns have also been observed for mesopelagic fishes spawning at the subsurface in the shelf break of this upwelling area (Vargas \& Castro 2001, Landaeta \& Castro 2002) and for mesopelagic copepods that approach the coast to reproduce during the upwelling season (Castro et al. 1993).

From the other extreme of adult habitat depth range, Emerita analoga presented a contrasting pattern. E. analoga was also widespread horizontally, but it was very shallow, its depth range was more restricted than that of Libidoclaea granaria. Larvae are released in the intertidal zone and although highest concentrations of Stage I were found close to shore, high offshore advection was evident even for this first stage. The annual bimodal spawning pattern of E. analoga in late summer (this study) and also in winter (Contreras et al. 1999) differs from the unimodal pattern of larval release of $E$. brasiliensis from the Atlantic coast at approximately the same latitude (Delgado \& Defeo, 2006). Since closely related species from the same habitat tend to develop convergent strategies when faced to similar environmental pressures, we proposed that the oceanographic setting (seasonal upwelling dynamics) in south central Chile influences the timing of E. analoga larval release. E. analoga increases its offshore distance at intermediate stages, and approaches the coast again during Stage V (both cruises). The mechanism by which this transition is 
accomplished is not clear from our study. Behaviour is strongly suggested by the fact that clumping decreases from early zoea to intermediate ones, and then it increases again. This pattern has been recognized in larval fish and attributed to behavioural concentration as larvae progress through ontogeny (Bradbury et al. 2003). The behavioural mechanism that accomplishes return to coastal habitat is usually a deepening of late zoeas. If ontogenetic depth changes are subtle, our depth resolution might not be able to detect them and only a slight evidence of late zoea deepening appeared during the March cruise.

Blepharipoda spinimana, the second intertidal species, was always restricted to very coastal stations and it spawned mainly during summer. Although development should be shorter than Emerita analoga, this fact alone cannot account for the differences in spatial distribution observed, since even Stage I Emerita analoga was distributed further offshore than B. spinimana. The depth range and absolute depth were lowest for $B$. spinimana, however, since it was sampled only over shallow strata, and depth distribution is correlated with station depth, these comparisons might not be informative. Yannicelli et al. (2006) showed that $B$. spinimana could be retained within the gulf of Arauco during the upwelling season by regulating its depth distribution. Such a regulation cannot be assessed by the present sampling scheme, however, its restricted coastal distribution is in agreement with the prediction from previous results. Since the vertical structure of flow changes is within a few meters near the coast, it should not be necessary for larvae to perform large vertical excursions in order to remain nearshore.

Larvae of pagurids and Neotrypaea uncinata, the 2 subtidal taxa, showed quite remarkable similarities regarding spatial and temporal distribution patterns. Their larval abundance was higher in March and their stage temporal distribution indicate that spawning occurred during a long period but peaked during summer. For $N$. uncinata, diel vertical migration was evident as well as a deepening from Stage I to III and IV during daytime. Yannicelli et al. (2006) reported ontogenetic deepening of zoea IV and V in $N$. uncinata, which cannot be fully addressed in the present study because its late stages are concentrated in coastal shallow stations; they also reported a tendency of pagurids to present diel vertical movements and the present study confirms a vertical migration for zoea IV. The ontogenetic pattern of vertical distribution caused offshore early larval transport and late stages inflow to the gulf of Arauco. Accordingly, during the present study, older stages of both groups were closer to the shore.

In order to utilize the ontogenetic and dial vertical migration strategy for transport as well as remaining deep as Libidiclaea granaria, species should be highly tolerant to hypoxic conditions prevailing during the upwelling season even at the nearshore stations. Crustacean larvae have hardly been reported in very low oxygen concentrations, which are usually considered detrimental (Anger 2001). Adult thallasinids might inhabit poorly oxygenated tubes and sediments, and are known to be highly tolerant to hypoxic conditions (Miller et al. 1976). Adult L. granaria can also inhabit sediments bathed in hypoxic waters. In spite of the fact that larvae do not necessarily display the same physiological capabilities as adults, it is probable that these groups have developed high tolerance to hypoxia since they are released in hypoxic waters overlaying adult habitat.

It has been suggested that species which spawn before the main upwelling season would spread farther because they would be displaced offshore (Wing et al. 1998b). In this case, Libidoclaea granaria spawns earlier during the upwelling season and Stage I is, in fact, distributed further offshore. However, Emerita analoga whose main peak occurred during March, at the transition period, also distributed offshore in spite of its coastal release site. Therefore, other factors should be identified. For L. granaria wide distribution should be due to its wide release site over the shelf, and for E. analoga, to its surface preference and long larval development.

Overall, the larval release timing observed for the present species together with their vertical distribution, agrees with that presented for larval fish in upwelling areas (Olivar 1990). Species released off phase with maximum upwelling intensities are distributed in surface waters, and those that are released during more intense upwelling periods are deeper and more widespread in the water column. That such a pattern is repeated in such different taxa denotes the strong effect of the advective environment, through its influence on early life history, on adult benthic population dynamics. Also, vertical migrating species seem to have a wide larval release period during upwelling seasons. Organisms that have the capability of regulating their positioning in the water column could become more independent of physical oceanographic processes, and therefore spawning timing could be more influenced by other factors such as temperature or productivity. In this area, besides phylogenetic development of migratory capacity, the vertical migratory capability of some taxa might be constrained by physiological tolerances to low oxygen and temperature. Therefore, the resulting spatial distribution displayed by the larvae is influenced by the spatial structure of upwelling circulation, the larval tolerances to the chemical environment and larval behavioural responses as development progresses. 
Acknowledgements. This research was funded by the Chilean national FONDECYT project 1010900 to W.S., R.R. and L.R.C. B.Y. was supported by the German Academic Exchange Service (DAAD) doctoral scholarship, and recently by Mecesup project UCO002. We acknowledge the cooperation of RV 'Abate Molina' crew at sea. We also thank C. Krautz, M. Landaeta and M. Pavez for their support before, during and after the cruises. We acknowledge J. Garces, R. Fuenzalida, J. Placencia and M. Gutierrez for their collaboration during oceanographic data gathering. R. Roa has provided thoughtful discussion on survey data distributions.

\section{LITERATURE CITED}

Anger K (2001) The Biology of Decapod Crustacean Larvae. Crustacean Issues 14:1-420

Arcos DF, Navarro N (1986) Análisis de un índice de surgencia para la zona de Talcahuano, Chile (lat. $37^{\circ} \mathrm{S}$ ). Invest Pesq 33:91-98

Aste A (1982) Desarrollo larval de dos especies de Callianassa (Crustacea, Decapoda, thalassinidea) bajo condiciones de laboratorio. Bachelor dissertation, Universidad de Concepción, Concepción, Chile

Atkinson LP, Valle-Levinson A, Figueroa D, De Pol-Holz R, Gallardo VA, Schneider W, Blanco JL, Schmidt M (2002) Oceanographic observations in Chilean coastal waters between Valdivia and Concepción. J Geophys Res 107(C): 10.1029/2001JC000991

Bez N (2000) On the use of Lloyd's index of patchiness. Fish Oceanogr 9:372-376

Bjorkstedt ER, Grantham BA, Shkedy Y, Rosenfeld L, Roughgarden J (1997) Ichthyoplankton distribution at coastal upwelling fronts off central California: implications for larval transport. Ichthyoplankton Ecol 5

Botsford LW (2001) Physical influences on recruitment to California Current invertebrate populations on multiple scales. ICES J Mar Sci 58:1081-1091

Bradbury IR, Snelgrove PVR, Pepin P (2003) Passive and active behavioral contributions to patchiness and spatial pattern during the early life history of marine fishes. Mar Ecol Prog Ser 257:233-245

Castro LR, Bernal PA, Troncoso VA (1993) Coastal intrusion of copepods: mechanisms and consequences on the population biology of Rhincalanus nasutus. J Plankton Res 15: 501-515

Castro LR, Salinas GR, Hernandez EH (2000) Environmental influences on winter spawning of the anchoveta Engraulis ringens off Central Chile. Mar Ecol Prog Ser 197:247-258

Concha MC (1978) Contribución al estudio de las larvas de decapoda crustácea, Bahía de Concepción, Chile. Bachelor dissertation, Universidad de Concepción, Concepción, Chile

Connolly SR, Roughgarden J (1998) A latitudinal gradient in northeast Pacific intertidal community structure: evidence for an oceanographically based synthesis of marine community theory. Am Nat 151:311-326

Connolly SR, Menge BA, Roughgarden J (2001) A latitudinal gradient in recruitment of intertidal invertebrates in the northeast Pacific Ocean. Ecology 82:1799-1813

Contreras H, Defeo O, Jaramillo E (1999) Life history of Emerita analoga (Stimpson) (Anomura, Hippidae) in a sandy beach of south central Chile. Estuar Coast Shelf Sci 48:101-112

Cury P, Roy C (1989) Optimal environmental window and pelagic fish recruitment success in upwelling areas. Can J Fish Aquat Sci 46:670-680

Daneri G, Dellarossa V, Quiñones R, Jacob B, Montero P,
Ulloa O (2000) Primary production and community respiration in the Humboldt Current System off Chile and associated oceanic areas. Mar Ecol Prog Ser 197:41-49

Delgado E, Defeo O (2006) A complex sexual cycle in sandy beaches: the reproductive strategy of Emerita brasiliensis (Decapoda: Anomura). J Mar Biol Assoc UK 86:361-368

Djurfeltd L (1989) Circulation and mixing in a coastal upwelling embayment; Arauco Gulf, Chile. Cont Shelf Res 9:1003-1016

Faguetti E (1969) The larval development of the spider crab Libodoclaea granaria H Milne Edwards \& Lucas under laboratory conditions (Decapoda Brachyura, Majidae, Pisinae). Crustaceana 17:131-140

Flores AAV, Cruz J, Paula J (2002) Temporal and spatial patterns of settlement of brachyuran crab megalopa at a rocky coast in Central Portugal. Mar Ecol Prog Ser 229: 207-220

Forward RB Jr, Tankersley RA (2001) Selective tidal-stream transport of marine animals. Oceanogr Mar Biol Annu Rev 39:305-353

Garland ED, Zimmer CA, Lentz SJ (2002) Larval distributions in inner-shelf waters: the roles of wind-driven cross-shelf currents and diel vertical migration. Limnol Oceanogr 47: 803-817

Gill AE (1982) Atmosphere-Ocean Dynamics. Academic Press

Guisande C, Cabanas JM, Vergara AR, Riveiro I (2001) Effect of climate on recruitment success of Atlantic Iberian sardine Sardina pilchardus. Mar Ecol Prog Ser 223:243-250

Hernández-León S, Almeida C, Portillo-Hahnefeld A, Gomez M, Rodriguez JM, Aristegui J (2002) Zooplankton biomass and indices of feeding and metabolism in relation to an upwelling filament off Northwest Africa. J Mar Res 60: 327-346

Hinckley S, Hermann AJ, Mier KL, Megrey BA (2001). Importance of spawning location and timing to successful transport to nursery areas: a simulation study of Gulf of Alaska walleye pollock. ICES J Mar Sci 58:1042-1052

Johnson MW, Lewis WM (1942) Pelagic larval stages of the sand crabs Emerita analoga Stimson, Blepharipoda occidentalis Randall, and Lepidopa myops Stimson. Biol Bull 83(1):67-87

Kasai A, Kimura S, Nakata H, Okazaki Y (2002) Entrainment of coastal water into a frontal eddy of the Kuroshio and its biological significance. J Mar Syst 37:185-198

Landaeta M, Castro LR (2002) Spring spawning and early nursery zone of the mesopelagic fish Maurolicus parvipinnis at the coastal upwelling zone off Talcahuano, central Chile. Mar Ecol Prog Ser 226:179-191

Lavados G (1982) Desarrollo larval de Pagurus edwarsi (Dana,1852) (Crustacea, Decapoda) bajo condiciones de laboratorio. Bachelor dissertation, Universidad de Concepción, Concepción, Chile

Lundquist CJ, Botsford LW, Morgan LE, Diehl JM, Lee T, Lockwood DR, Pearson EL (2000) Effects of El Niño and La Niña on local invertebrate settlement in northern California. Cal COFI Rep 41:167-176

Mesias JM, Matano RP, Strub PT (2001) A numerical study of the upwelling circulation off central Chile. J Geophys Res 106(C9) 19611-19623

Mesias JM, Matano RP, Strub PT (2003) Dynamical analysis of the upwelling circulation off central Chile. J Geophys Res 108(C3), 3085, doi:101029/2001JC 001135

Miller KI, Pritchard AW, Rutledge PS (1976) Respiratory regulation and the role of the blood in the burrowing shrimp Callianassa californiensis (Decapoda: thalassinidea). Mar Biol 36:233-242 
Navarro E, Schneider W, Letelier J (2004) Estimation of onshore-offshore transport off central Chile by means of Maximum Cross-Correlation using satellite derived SST. Gayana 68(2):427-431

Naylor E (2005) Chronobiology: implications for marine resource exploitation and management. Sci Mar 69: 157-167

Nishimoto MM, Washburn L (2002) Patterns of coastal eddy circulation and abundance of pelagic juvenile fish in the Santa Barbara Channel, California, USA. Mar Ecol Prog Ser 241:183-199

Olivar MP (1990) Spatial patterns of ichthyoplankton distribution in relation to hydrographic features in the northern Benguela region. Mar Biol 106:39-48

Palma S, Arana P (1997) Aspectos reproductivos de langostino Colorado (Pleuroncodes monodon H. Milne Edwards, 1937), frente a la costa de Concepción, Chile. Invest Mar Valparaiso 25:203-221

Pennington M (1983) Efficient estimators of abundance for Fish and Plankton surveys. Biometrics 39:281-286

Peterson WT, Miller CB, Hutchinson A (1979) Zonation and maintenance of copepod populations in the Oregon upwelling zone. Deep-Sea Res 26A:467-494

Rodriguez JM, Barton ED, Hernández-León S (2001) Mesozooplankton and ichthyoplankton distribution around Gran Canaria, an oceanic island in the NE Atlantic. DeepSea Res I 48:2161-2183

Shanks AL (2000) Demonstration of the onshore transport of larval invertebrates by the shoreward movement of an upwelling front. Limnol Oceanogr 45:230-236

Shanks AL, Largier J, Brink L, Brubaker J, Hooff R (2002) Observations on the distribution of meroplankton during a downwelling event and associated intrusion of the Chesapeake Bay estuarine plume. J Plankton Res 24:391-416

Shanks AL, Largier J, Brubaker J (2003) Observations on the distribution of meroplankton during an upwelling event. J Plankton Res 25:645-667

Sobarzo M, Djurfeldt L (2004) Coastal upwelling process on a continental shelf limited by submarine canyons, Concepción, central Chile. J Geophys Res 109, C12012, doi:10.1029/2004JC002350

Sobarzo M, Yannicelli B, Castro L, Landaeta M, Schneider W (2004) Topographic control of the larval clupeiform distribution in the coastal upwelling area off Concepción, Cen-

Editorial responsibility: Kenneth Sherman (Contributing Editor), Narragansett, Rhode Island, USA tral Chile. Small Pelagic Fish Spawning Habitat Dynamics and the Daily Egg Production Method (DEPM) Globec meeting. Concepción, Chile 12-16 January 2004

Sorte CJ, Peterson WT, Morgan CA, Emmett RL (2001) Larval dynamics of the sand crab, Emerita analoga, off the central Oregon coast during a strong El Niño period. J Plankton Res 23:939-944

Sponaugle S, Cowen RK, Shanks A, Morgan SG and 7 others (2002) Predicting self-recruitment in marine populations: biophysical correlates and mechanisms. Bull Mar Sci 70: 341-375

Stenevik EK, Skogen M, Sundby S, Boyer D (2003) The effect of vertical and horizontal distribution on retention of sardine (Sardinops sagax) larvae in the Northern Benguela observations and modelling. Fish Oceanogr 12:185-200

Sundby S, Boyd AJ, Hutchings L, O'Toole MJ, Thorisson K, Thorsen A (2001) Interaction between Cape hake spawning and the circulation in the northern Benguela upwelling ecosystem. S Afr J Mar Sci 23:317-336

Valle-Levinson A, Atkinson LP, Figueroa D, Castro L (2003) Flow induced by upwelling winds in an equatorward facing bay: Gulf of Arauco, Chile. J Geophys Res 108(C2), 3054, doi:10.1029/2001JC001272

Vargas C, Castro LR (2001) Spawning of the chilean hake (Merluccius gayi) in the upwelling system off Talcahuano in relation to oceanographic features. Sci Mar 65:101-110

Wing SR, Botsford LW, Quinn JF (1998a) The impact of coastal circulation on the spatial distribution of invertebrate recruitment, with implications for management. Can Spec Publ Fish Aquat Sci 125:285-294

Wing SR, Botsford LW, Ralston SV, Largier JL (1998b) Meroplanktonic distribution and circulation in a coastal retention zone of the northern California upwelling system. Limnol Oceanogr 43:1710-1721

Yannicelli B (2005) Distribución y transporte de larvas de crustáceos decápodos en la zona de surgencia costera de Chile Central: interacciones entre el comportamiento, tolerancias fisiológicas y períodos de liberación. PhD dissertation, Universidad de Concepción, Concepción, Chile

Yannicelli B, Castro LR, Valle-Levinson A, Atkinson L, Figueroa D (2006) Vertical distribution of decapod larvae in the entrance of an equatorward facing bay of central Chile: implications for transport. J Plankton Res 28:19-37 doi:10.1093

Submitted: August 12, 2004; Accepted: December 18, 2005 Proofs received from author(s): July 7, 2006 